\title{
Geotechnical characterization of Panki and Panipat pond ash in India
}

\author{
Supriya Mohanty ${ }^{1 *}$ and Nihar Ranjan Patra ${ }^{2}$
}

\author{
${ }^{*}$ Correspondence: \\ supriya.mohanty88@gmail. \\ com; supriya.mohanty@iiit. \\ ac.in \\ ${ }^{1}$ Earthquake Engineering \\ Research Centre, \\ International Institute \\ of Information Technology, \\ Hyderabad, Telangana \\ 500032, India \\ Full list of author information \\ is available at the end of the \\ article
}

\begin{abstract}
Rapid growth in thermal power plants acquires huge valuable lands for disposing coal ash generated as a waste material from thermal power plants. In most of the thermal power plants, the coal ash is dumped in the nearby low lying areas which results into the formation of ash pond. Pond ash can be effectively used for various geotechnical applications such as, filling low lying areas, construction of highways and embankments to minimize the disposal problem. The utilization of pond ash in geotechnical engineering applications needs thorough understanding of its physical, chemical, mineralogical, morphological and engineering properties. This paper presents a detailed geotechnical characterization of pond ashes collected from Panki and Panipat thermal power plants which comes under seismic zone III and IV respectively. From the laboratory studies, it is observed that Panki and Panipat pond ashes show low specific gravity (2.21-2.338), good drainage characteristics (2.42E-05 m/s to $4.21 \mathrm{E}-05 \mathrm{~m} / \mathrm{s})$ and good friction properties $\left(33.04^{\circ}-36.53^{\circ}\right)$. So it can be effectively used for embankment construction, backfill material, filter material etc.
\end{abstract}

Keywords: Pond ash, Grain size, Chemical properties, Compaction, Consolidation, Triaxial test

\section{Background}

In India huge quantities of coal ash are generated as a waste material from thermal power plants. The annual production of coal ash in India is about 112 million metric tons and its disposal is a major problem. It has been observed that in most of the thermal power plants, the coal ash is dumped in the nearby low lying areas which produces "ash pond". These ash ponds have already occupied 65,000 acres of valuable land in India [22]. Recent study shows that fly ash is a highly heterogeneous material showing different chemical and mineralogical behavior of similar size particles. Characteristic of high calcium fly ash is expected to vary more from source to source and time to time than low calcium fly ash [3]. From literatures [16, 20, 25, 30,31] it can be observed that low calcium fly ashes can be effectively used for embankment construction and filling of low lying areas. Use of fly ash as a replacement to cement has been reported by Gopalan and Haque [4]. Joshi et al. [13] investigated use of lime-fly ash slurry for ground improvement application. Studies related to fly ash characterization with reference to geotechnical application has been reported by many researchers $[2,15,28]$. Very few researchers have attempted to study the geotechnical characterization of pond ash [12, 26]. Hence, the

(c) 2015 Mohanty and Patra. This article is distributed under the terms of the Creative Commons Attribution 4.0 International License (http://creativecommons.org/licenses/by/4.0/), which permits unrestricted use, distribution, and reproduction in any medium, provided you give appropriate credit to the original author(s) and the source, provide a link to the Creative Commons license, and indicate if changes were made. 
use of pond ash in geotechnical application needs through understanding of its physical and chemical properties, and engineering behavior. In the present study, geotechnical characterization of pond ash samples collected from Panki and Panipat thermal power plants under seismic zone III and IV respectively have been reported. Few geotechnical properties of Panki and Panipat pond ash like, specific gravity, grain size, maximum dry unit weight and angle of friction are presented in Mohanty and Patra [19]. The detailed geotechnical characterization of Panki and Panipat pond ash including X-ray diffraction (XRD), X-ray fluorescence (XRF), Scanning electron microscope (SEM), consolidation, permeability and consolidated undrained behavior are presented in the present study. Special attention has been made to study the applicability of low calcium pond ash in geotechnical engineering filed.

\section{Materials used}

In the present study pond ash samples has been collected from two different seismic zone sites in India namely Panki thermal power station (Kanpur, Uttar Pradesh) and Panipat thermal power station (Panipat, Haryana) sites which comes under seismic zone III and IV respectively (IS:1893-Part 1 [11]). All the ash samples were collected from upstream sites of the ash pond embankments. Based on chemical analysis both the pond ashes are classified as class "F" (ASTM C [1]). Table 1 shows chemical compositions of both the pond ashes.

\section{Experimental investigation}

Pond ash samples collected from Panki and Panipat thermal power stations have been tested in the laboratory to investigate its physical and chemical properties, and engineering behavior. The physical properties of the pond ash like specific gravity have been determined for both the pond ashes. X-ray diffraction (XRD) technique has been used to determine atomic structure of crystalline substances present in the pond ash samples. $\mathrm{X}$-ray fluorescence (XRF) has been carried out to analyze the major oxides (in weight \%) and selected trace elements (in ppm) present in the samples. Scanning electron microscope (SEM) studies have been carried out for both the pond ashes to study the individual morphology of pond ash particles. To study geotechnical properties of pond ash

Table 1 Chemical composition (\%) of Panki and Panipat pond ashes

\begin{tabular}{lcr}
\hline Chemical composition (\%) & Panki & Panipat \\
\hline Silicon dioxide $\left(\mathrm{SiO}_{2}\right)$ & 61.1958 & 60.3834 \\
Aluminum oxide $\left(\mathrm{Al}_{2} \mathrm{O}_{3}\right)$ & 24.0838 & 30.0436 \\
Iron oxide $\left(\mathrm{Fe}_{2} \mathrm{O}_{3}\right)$ & 9.8135 & 3.7632 \\
Potassium oxide $\left(\mathrm{K}_{2} \mathrm{O}\right)$ & 1.7609 & 1.9345 \\
Titanium oxide $\left(\mathrm{TiO}_{2}\right)$ & 1.4687 & 1.8572 \\
Calcium oxide $(\mathrm{CaO})$ & 0.6018 & 0.8119 \\
Magnesium oxide $(\mathrm{MgO})$ & 0.5782 & 0.5246 \\
Phosphorous pentoxide $\left(\mathrm{P}_{2} \mathrm{O}_{5}\right)$ & 0.2472 & 0.3613 \\
Sulfur trioxide $\left(\mathrm{SO}_{3}\right)$ & 0.1069 & 0.151 \\
Sodium oxide $\left(\mathrm{Na}_{2} \mathrm{O}\right)$ & 0.133 & 0.1441 \\
Strontium oxide $(\mathrm{SrO})$ & 0.0102 & 0.0252 \\
\hline
\end{tabular}


samples, grain size distribution, compaction, consolidation, permeability and consolidated undrained (CU) triaxial shear tests have been carried out for both the pond ash samples. The pond ashes tested consist of mostly sands and have low calcium. They are non-plastic materials. Hence, it is no need to do the consistency test for the pond ash material.

\section{Testing methods and sample preparation Specific gravity test}

The specific gravity test of pond ash samples collected from Panki and Panipat thermal power stations has been carried out as per IS: 2720-Part 3 [5] with distilled water and deaired by heating on sand bath.

\section{Mineralogy analysis using X-ray diffraction (XRD) test}

About 10 gm of pond ash sample (passing through $75 \mu \mathrm{m}$ IS sieve) was taken in a glass beaker and $5 \mathrm{ml}$ of deaired water was added to it. Then the prepared solution was randomly mounted on a glass slide and kept in desiccators for $24 \mathrm{~h}$. After that the sample slide was ready for mineralogy analysis. All X-ray diffraction tests were performed using the facility available at the Advanced Center for Materials Sciences (ACMS), Indian Institute of Technology Kanpur (IITK). Prepared samples were run on $\mathrm{Cu}-\mathrm{K} \alpha$ $(\lambda=1.5418 \AA$ ) source, 122 Phillip Diffractometer (40 kV potential difference and $25 \mathrm{~mA}$ current) at scan speed $1^{\circ} / \mathrm{min}$, step size of $0.02^{\circ}$ and $2 \theta$ in the range of $5^{\circ}-75^{\circ}$.

\section{X-ray fluorescence (XRF) test}

About $6 \mathrm{~g}$ of pond ash sample (passing through $75 \mu \mathrm{m}$ IS sieve) was taken and $0.6 \mathrm{gm}$ of boric acid was added to prepare the sample. In order to remove moisture from the sample, the prepared samples were heated at $100^{\circ} \mathrm{C}$ in the oven for $1 \mathrm{~h}$, then the samples were grinded for complete homogeneity and then passed through $63 \mu \mathrm{m}$ sieve (ASTM \# 230). After that pressed powder pellets were prepared at the Advanced Center for Materials Sciences (ACMS), Indian Institute of Technology Kanpur (IITK) with the help of stainless steel dye-cast having a diameter of $30 \mathrm{~mm}$. Then samples were pressed on a hydraulic pre machine with a pressure of $12-13$ ton to make $30 \mathrm{~mm}$ diameter pressed powder pellets and heated in oven for $1 \mathrm{~h}$ at $60{ }^{\circ} \mathrm{C}$ to remove any moisture absorbed by the pellets. All the X-ray fluorescence tests were carried out using the Rigaku ZSX primus II wavelength dispersive X-ray fluorescence spectrometer (WDXRF) available in the Advanced Center for Materials Sciences (ACMS), Indian Institute of Technology Kanpur (IITK). The instrument generates X-ray from cathode plate made up of Rh at $4 \mathrm{KW}$ power on end type X-ray generator. All the tests were carried out in vacuum at $50 \mathrm{kV}$ and $60 \mathrm{~mA}$.

\section{Scanning electron microscope (SEM) test}

The morphological characteristics of the pond ash samples collected from Panki and Panipat thermal power stations has been carried out using scanning electron microscope (SEM) techniques available at the Advanced Center for Materials Sciences (ACMS), Indian Institute of Technology Kanpur (IITK). About $1 \mathrm{gm}$ of pond ash sample was taken and placed on the instrument stub. Due to non conductive nature of pond ash 
sample, gold coating has been carried out to provide a conductive thin layer. Then introduce the sample stub into the SEM vacuum chamber and activate the electron beam when vacuum conditions meet those recommended by the manufacturer. All the SEM tests were carried out using Zeiss EVO 50 SEM equipment with EHT voltage of $15 \mathrm{kV}$ and $7.5 \mathrm{~mm}$ of WD for different magnification.

\section{Grain size distribution}

Grain size distribution (as per IS: 2720-Part 4 [8]) for Panki and Panipat pond ashes were carried out to determine the particle size of the pond ash samples. First sieve analysis has been carried out for both the pond ashes and the mass of pond ash passing through $75 \mu$ sieve was taken for hydrometer analysis. The results of sieve and hydrometer analysis have been used for the gradation of pond ash materials.

\section{Compaction characteristics}

In order to determine the maximum dry unit weight and optimum moisture content (OMC) of the Panki and Panipat pond ash samples standard proctor tests was carried out as per IS: 2720-Part 7 [6]. Oven dried pond ash sample has been thoroughly mixed with sufficient quantity of water. The mixture was then placed into the proctor mould and compacted in three layers giving 25 blows per layer with a $2.5 \mathrm{~kg}$ rammer dropped from a height of $30 \mathrm{~cm}$. The procedure has been repeated by increasing the amount of water until a decrease or no change in the wet unit weight of the compacted pond ash sample.

\section{Compressibility characteristics}

Compressibility characteristics of the pond ash samples have been investigated from one dimensional consolidation tests (as per IS: 2720-Part 15, [9]). Pond ash samples were prepared at a relative density of 50 and $65 \%$ and compacted using a standard manual rammer. Then the sample was placed in a consolidation ring and soaked for $24 \mathrm{~h}$ with seating load of $5 \mathrm{kPa}$. After that loading and unloading has been carried out according to IS 2720 .

\section{Permeability characteristics}

The coefficient of permeability $(\mathrm{k})$ of Panki and Panipat pond ash sample has been determined from the falling head permeameter. The falling head permeability test was carried out as per IS: 2720-Part 17 [10] using a rigid wall compaction mould permeameter. Pond ash samples were prepared at a relative density of 50 and $65 \%$ and placed into the permeameter using standard compaction technique. Then the sample was saturated by using deaired water. Inlet nozzle of the mould was connected to the stand pipe and flow of water was allowed until the steady flow. After that the time interval for a fall of head in the stand pipe has been noted and was repeated five times to determine the time interval for the same head.

\section{Consolidated undrained triaxial shear test}

In order to determine the shear strength parameters of the pond ash samples consolidated undrained triaxial shear test were carried out as per the procedure given in IS: 
2720-Part 12 [7]. Here, moist tamping technique has been employed for the preparation of $50 \mathrm{~mm}$ diameter and $100 \mathrm{~mm}$ height pond ash samples at relative density of 50 and $65 \%$. Selection of quantity of water for a particular density has been chosen based on the ability of the sample to stand by itself. Each sample was prepared in three layers by compacting with tamping rod (nearly $48 \mathrm{~mm}$ diameter) and giving fixed number of blows to each layer. Then filter paper and porous stone was placed on top and bottom of the sample. After this rubber membrane was pulled over the sample and the assembly was sealed with o-ring. Then saturation process was continued until the $\mathrm{B}$ (Pore Pressure Parameter $\mathrm{B}, \mathrm{B}=\Delta \mathrm{u} / \Delta \sigma_{\mathrm{c}}, \Delta \mathrm{u}=$ change in pore pressure, and $\Delta \sigma_{\mathrm{c}}=$ change in confining pressure) value reached beyond 0.98 . After that consolidation process was carried out to a desired effective confining pressure and the change in volume was recorded. Finally, shearing was done under confining pressure of 100, 200 and $300 \mathrm{kPa}$.

\section{Results and discussion}

\section{Specific gravity test}

Specific gravity is an important physical property to study the applicability of pond ash in geotechnical field. The specific gravity test has been carried out for both the pond ashes. The specific gravity of Panki and Panipat pond ashes were found to be 2.338 and 2.21 respectively [19] which lie in the range of specific gravity of Indian coal ashes [29]. From the test results it has been observed that pond ash sample collected from Panki and Panipat thermal power station shows lower specific gravity value than that of the natural soils. Panki pond ash shows little higher value than that of the Panipat pond ash. These low values of specific gravity causes the reduction in dry unit weight of the pond ash and make its utilization as a backfill material for retaining structures.

\section{Mineralogy analysis using X-ray diffraction (XRD) Test}

The XRD raw data, after removal of unwanted noise and spikes was processed using the Traces software version 6.6.10 (GBS Scientific Equipment Pty. Ltd.). The presence of inert minerals, are shown in Figs. 1, 2. From the XRD results it is found that Panki and Panipat pond ashes predominantly consist of quartz and feldspar minerals. Also the present results matches to the results of coal ashes reported by Powell et al. [23] and Gupta [27].

\section{X-ray fluorescence (XRF) test}

$\mathrm{X}$-ray fluorescence (XRF) has been carried out to analyze the major oxides (in weight $\%)$ and selected trace elements (in ppm) present in the pond ash samples. The major oxides and elements present in the Panki and Panipat pond ash samples are tabulated in Tables 1 and 2. From XRF results it is observed that the presence of calcium oxide is very low as compare to silica, alumina and iron oxides. The proportion of silica, alumina and iron oxides together is about $95 \%$ in both the pond ash samples, taking this into consideration the pond ash samples are classified as class F category (ASTM C [1]). The loss on ignition values for both Panki and Panipat pond ashes are below the maximum limit set for class F fly ashes. 


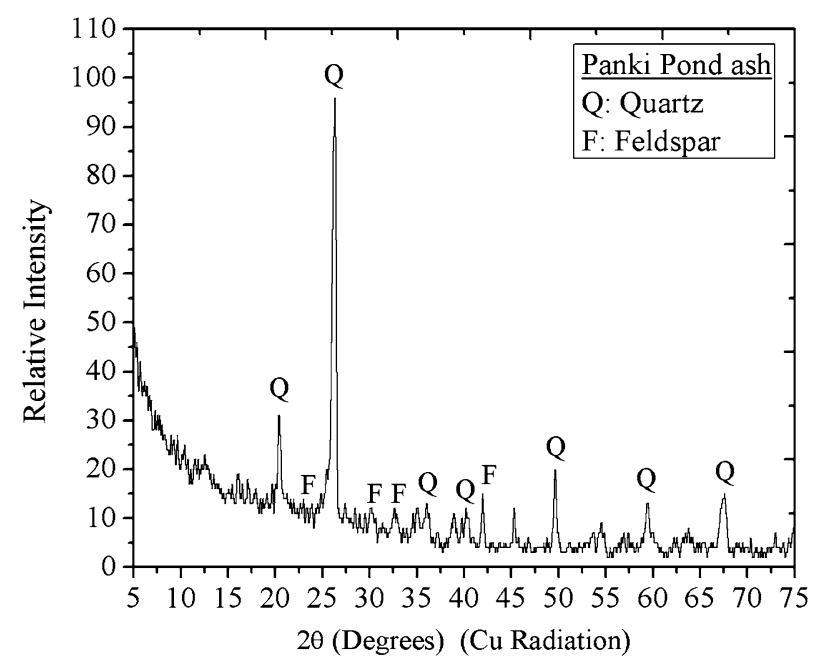

Fig. 1 X-ray diffraction pattern for Panki pond ash

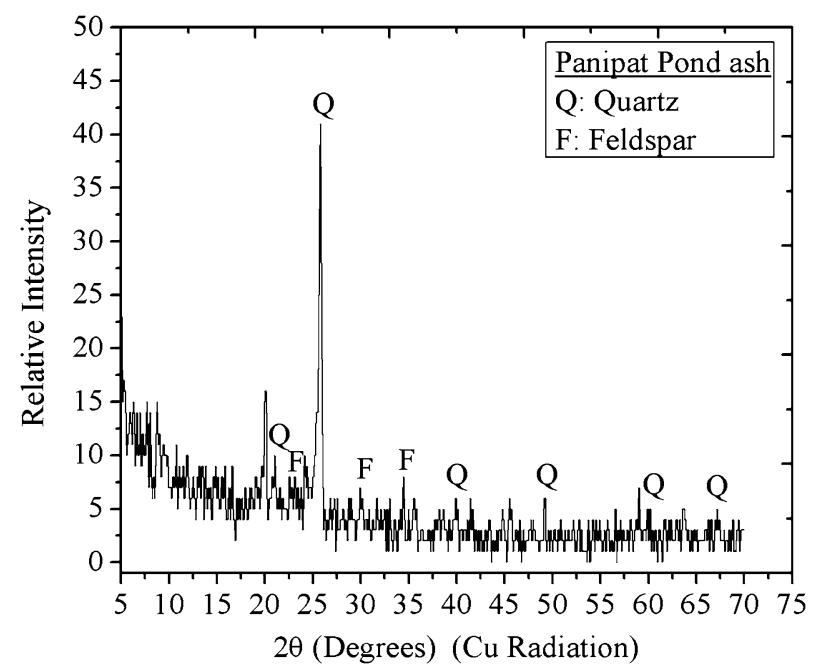

Fig. 2 X-ray diffraction pattern for Panipat pond ash

\section{Scanning electron microscope (SEM) test}

The morphological characteristics of the pond ash samples collected from Panki and Panipat thermal power stations has been carried out using scanning electron microscope (SEM) techniques available at the Advanced Center for Materials Sciences (ACMS), Indian Institute of Technology Kanpur (IITK). Typical results of Panipat pond ash sample tested at different magnifications are shown in Fig. 3. From Fig. 3 it can be noticed that the pond ash particles are composed of irregular and spherical in shape with complex pore structure. 
Table 2 Elements (\%) present in Panki and Panipat pond ashes

\begin{tabular}{lcc}
\hline Elements (\%) & Panki & Panipat \\
\hline $\mathrm{O}$ & 48.405 & 49.279 \\
$\mathrm{Si}$ & 28.605 & 28.226 \\
$\mathrm{Al}$ & 12.746 & 15.901 \\
$\mathrm{Fe}$ & 6.8639 & 2.6321 \\
$\mathrm{~K}$ & 1.4619 & 1.606 \\
$\mathrm{Ti}$ & 0.8805 & 1.1134 \\
$\mathrm{Ca}$ & 0.4301 & 0.5803 \\
$\mathrm{Mg}$ & 0.3487 & 0.3164 \\
$\mathrm{P}$ & 0.1079 & 0.1577 \\
$\mathrm{Na}$ & 0.0987 & 0.1069 \\
$\mathrm{~S}$ & 0.0428 & 0.0605 \\
$\mathrm{Sr}$ & 0.0086 & 0.0213 \\
\hline
\end{tabular}
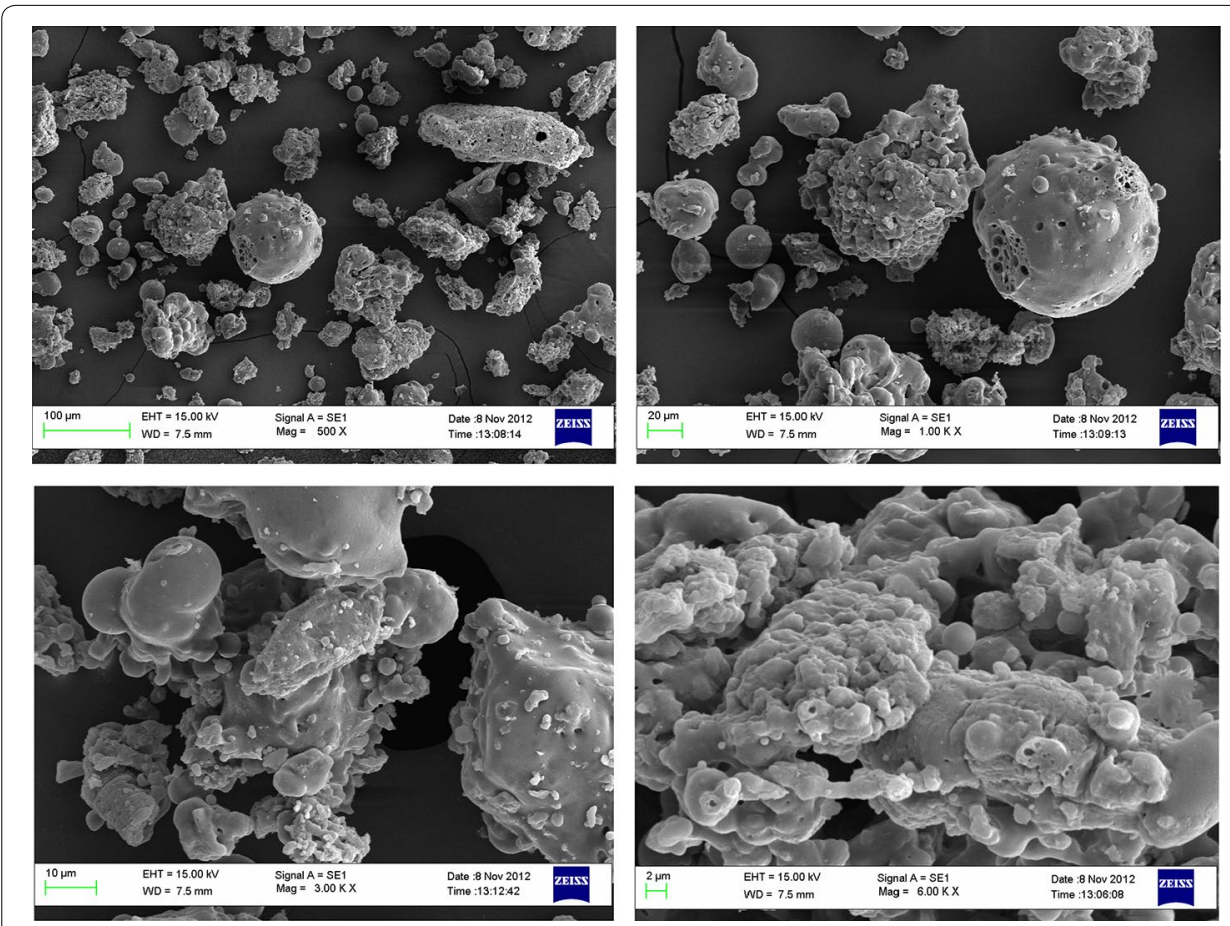

Fig. 3 Scanning electron micrographs of group and individual particles of Panipat pond ash

\section{Grain size distribution}

Grain size distribution analysis has been carried out for Panki and Panipat pond ashes. Figure 4 shows the grain size distribution curves of Panki and Panipat pond ashes. In the present study the pond ash samples were classified as per Unified Soil Classification System. From the grain size distribution curve, the percentage of silt, sand and clay fraction in Panki and Panipat pond ash are found to be 4.809, 95.167, 0 and 12.014\%, $87.243 \%, 0 \%$ respectively. Also it has been observed that pond ash samples collected from Panki and Panipat thermal power stations are in poorly graded sand and silty sand 


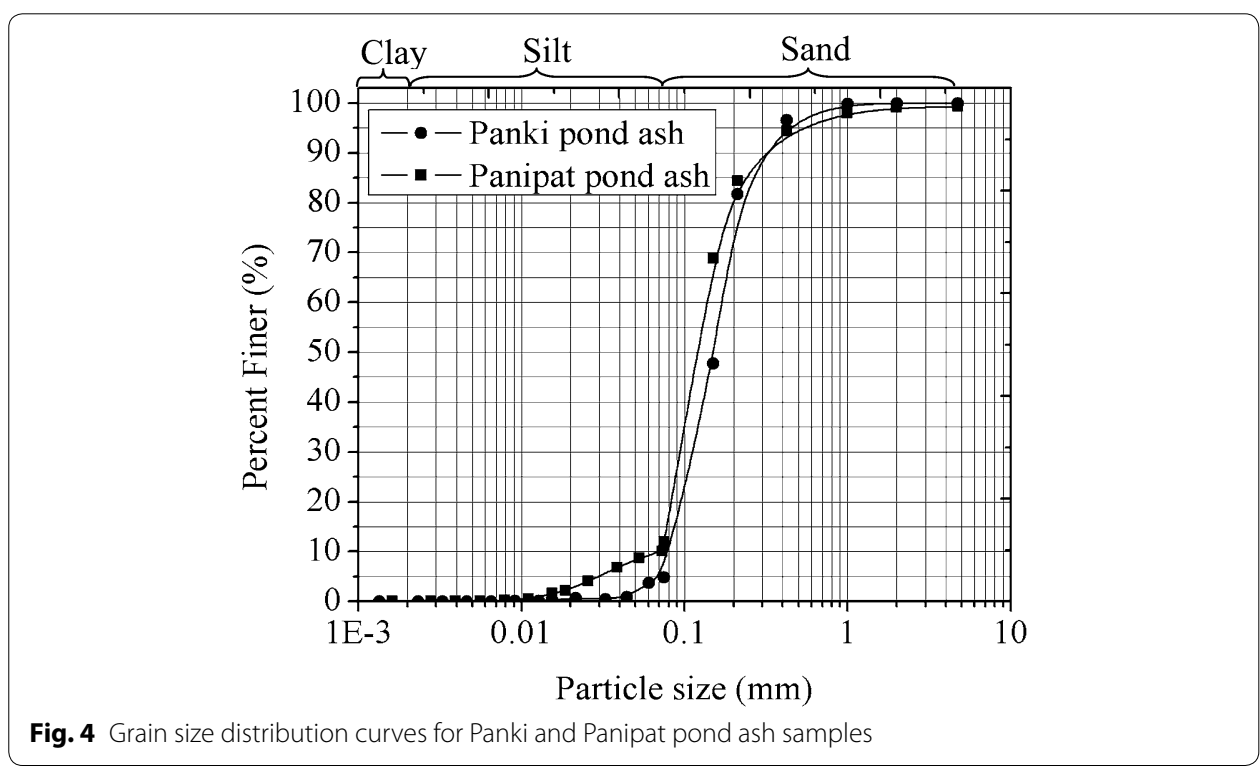

range respectively. The grain size distribution and gradation characteristics of Panki and Panipat pond ashes are tabulated in Table 3. The investigation shows that the major portions of pond ashes are coarser particles i.e. sand size fraction with some silt size fraction. The value of coefficient of uniformity and coefficient of curvature of the Panki and Panipat pond ashes is 2.25 and $0.84 ; 2.045$ and 0.736 respectively [19]. The present results are compared with the results reported by Pandian [21] for Indian coal ash. It has been observed that the present results are within the range of Indian coal ash.

\section{Compaction characteristics}

Standard proctor tests have been carried out to study the compaction characteristics of Panki and Panipat pond ash samples. Figure 5 shows the compaction curve for Panki and Panipat pond ash. The maximum dry unit weight and optimum moisture content of the Panki and Panipat pond ashes are $11.21 \mathrm{kN} / \mathrm{m}^{3}$ and $34.6 \% ; 10.4 \mathrm{kN} / \mathrm{m}^{3}$ and $42.14 \%$ respectively [19]. Panki pond ash shows higher dry unit weight as compare to

Table 3 Grain size characteristics of Panki and Panipat pond ashes

\begin{tabular}{lll}
\hline Properties & Panki & Panipat \\
\hline Gravel \% $(>4.75 \mathrm{~mm})$ & 0.024 & 0.743 \\
Sand \% $(4.75-0.075 \mathrm{~mm})$ & 95.167 & 87.243 \\
Silt \% $(0.002-0.075 \mathrm{~mm})$ & 4.809 & 12.014 \\
Clay \% $(<0.002 \mathrm{~mm})$ & 0 & 0 \\
Coefficient of uniformity $\left(C_{u}\right)$ & 2.25 & 2.045 \\
Coefficient of curvature $\left(C_{c}\right)$ & 0.8403 & 0.736 \\
$D_{10}$ size, $\mathrm{mm}$ & 0.08 & 0.07335 \\
$\mathrm{D}_{30}$ size, $\mathrm{mm}$ & 0.11 & 0.09 \\
$\mathrm{D}_{60}$ size, $\mathrm{mm}$ & 0.18 & 0.15 \\
Group symbol & $\mathrm{SP}$ & $\mathrm{SM}$ \\
Group name & Poorly graded sands with little fines & Silty sands \\
\hline
\end{tabular}




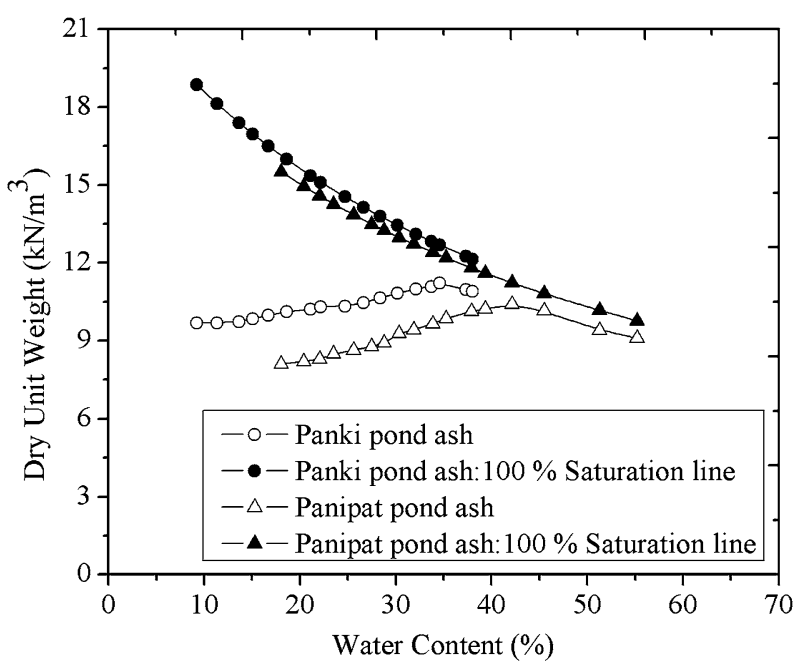

Fig. 5 Compaction curves for Panki and Panipat pond ash samples

Panipat pond ash. This is mainly due to the higher specific gravity value of Panki pond ash sample. It is observed that maximum dry unit weight and optimum moisture content are inversely correlated. Also it is clear that the compaction curve of Panki pond ash moves towards left due to the presence of coarser particles. The $100 \%$ saturation lines of both the pond ash samples have been plotted for their respective specific gravity values (Fig. 5). After comparing the present results with soils it is observed that maximum dry unit weight of pond ashes are lower than soils because of their lower specific gravity values [14]. Also it has been observed that maximum dry unit weight and optimum moisture content of the Panki and Panipat pond ashes are coming within the range of Indian fly ash [21].

\section{Compressibility characteristics}

In order to investigate the compressibility characteristics of the Panki and Panipat pond ash samples, one dimensional consolidation tests have been conducted considering the effect of relative density, degree of saturation, self hardening characteristics and pozzolanic activity on compression of pond ash. The compressibility of coal ashes reduces considerably with age hardening properties which in return reduce the time rate of consolidation as well as the magnitude of compressibility [18]. Similar observations have been noticed from the experimental investigations. Figures 6 and 7 shows the variation of void ratio with effective confining pressure for Panki and Panipat pond ash samples tested at 50 and $65 \%$ relative density respectively. From the test results, it is observed that Panipat pond ash shows high compressibility value as compare to Panki pond ash at 50 and $65 \%$ relative density. The compressibility characteristics of Panki and Panipat pond ashes are tabulated in Table 4. The compression index of Panki and Panipat pond ash samples varies from 0.083 to 0.132 and 0.169 to 0.344 respectively. Comparing these results with the available data for pond ash reported by Jakka et al. [12], it can be observed that Panki and Panipat pond ash shows higher compressibility value. 


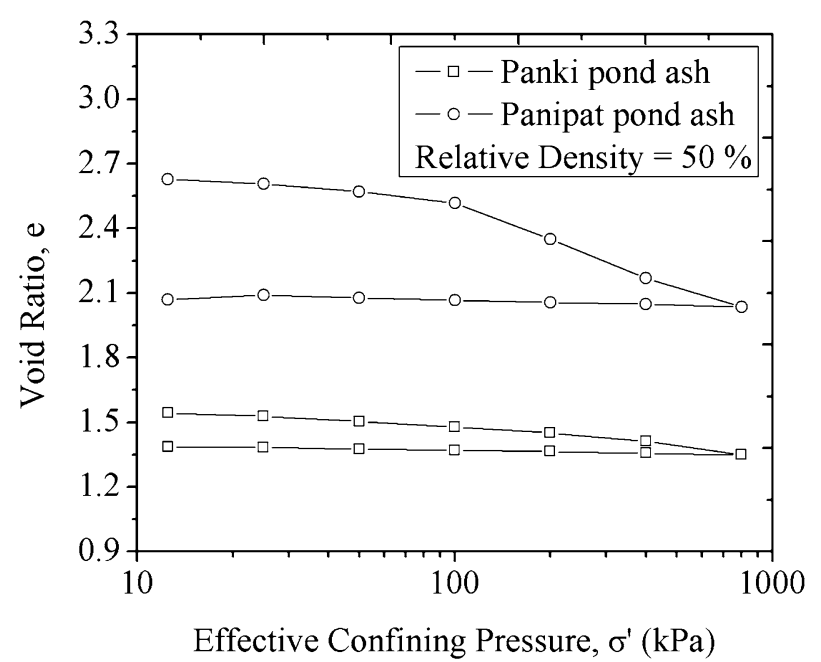

Fig. 6 Loading and unloading (e-log $\sigma^{\prime}$ ) curves for Panki and Panipat pond ash samples at $50 \%$ relative density

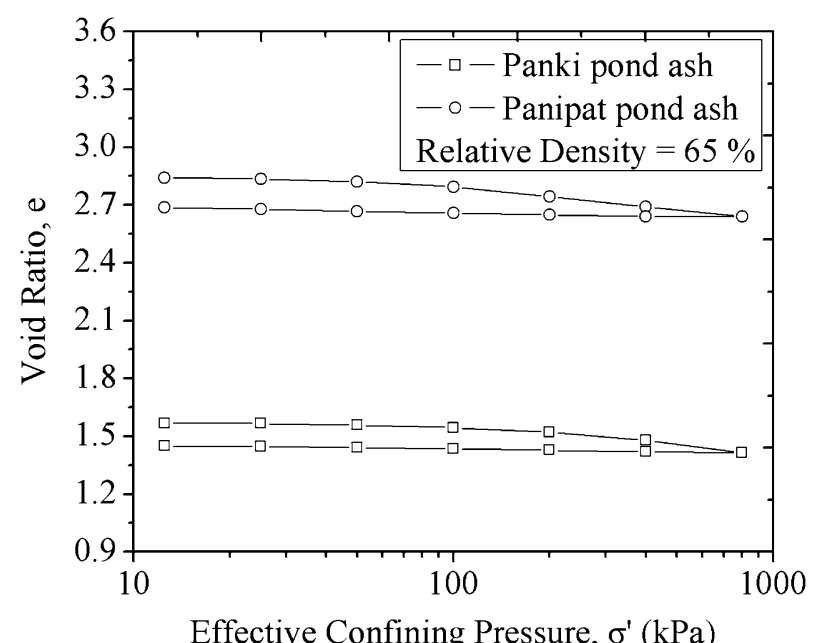

Fig. 7 Loading and unloading (e-log $\sigma^{\prime}$ ) curves for Panki and Panipat pond ash samples at $65 \%$ relative density

Table 4 Permeability and compressibility characteristics of Panki and Panipat pond ashes

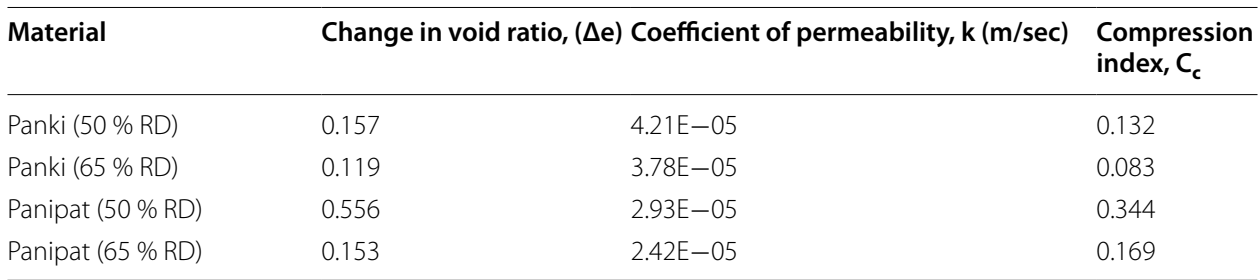




\section{Permeability characteristics}

Considering the presence of fine particles in the ash material falling head permeability test has been adopted to investigate the permeability characteristics of the pond ash samples. From the test results, it can be noticed that both Panki and Panipat pond ash tested at a relative density of 50 and $65 \%$ shows good drainage characteristics. The permeability characteristics of Panki and Panipat pond ashes are tabulated in Table 4. It has been observed that the coefficient of permeability of Panki and Panipat pond ash samples varies from $3.78 \mathrm{E}-05 \mathrm{~m} / \mathrm{s}$ to $4.21 \mathrm{E}-05 \mathrm{~m} / \mathrm{s}$ and $2.42 \mathrm{E}-05 \mathrm{~m} / \mathrm{s}$ to $2.93 \mathrm{E}-05 \mathrm{~m} / \mathrm{s}$ respectively which lies in the range of sandy soil. Panipat pond ash shows little lower coefficient of permeability values as compare to Panki pond ash because of the presence of silt size particles. By comparing the present results with the results of pond ash reported by Jakka et al. [12], it can be observed that Panki and Panipat pond ash shows little higher permeability value.

\section{Consolidated undrained triaxial shear test}

The situation where the pond ash is sheared under applied stress, excess pore pressure is produced that may not escape depending on the available time and drainage path. Such cases, strength parameters based on consolidated undrained (CU) test plays a vital role. From this test the relationship between induced excess pore water pressure and axial strain can be observed. In the present study shear strength properties of Panki and Panipat pond ashes are investigated by conducting series of consolidated undrained triaxial tests considering the effect of relative density (50 and $65 \%$ ) and confining pressure $(100,200$ and $300 \mathrm{kPa})$ on strength properties. The deformation rate of $0.6 \mathrm{~mm} / \mathrm{min}$ was maintained for all the tests. Figures 8, 9, 10, 11, 12, 13, 14, 15 show the results of variation of deviator stress and excess pore water pressure with axial strain. From the results it is observed that the behavior of deviator stress and excess pore water pressure with axial strain is similar for the two pond ash samples tested at different relative density (50 and $65 \%)$ and confining pressure $(100,200$ and $300 \mathrm{kPa})$. For all the confining pressure pond ash samples exhibited contractive behavior during static shear loading condition.

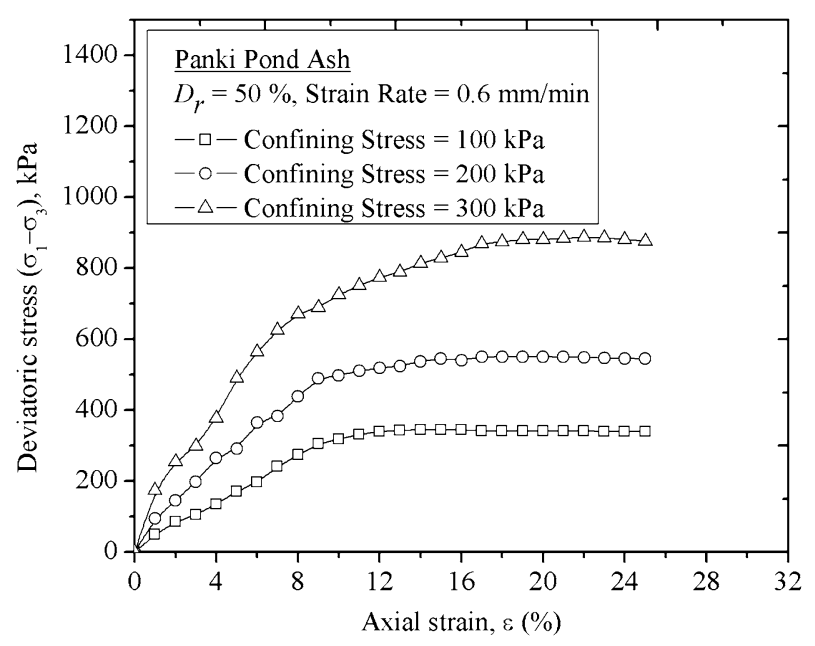

Fig. 8 Deviatoric stress vs. axial strain curve of Panki Pond Ash $\left(D_{r}=50 \%\right)$ 


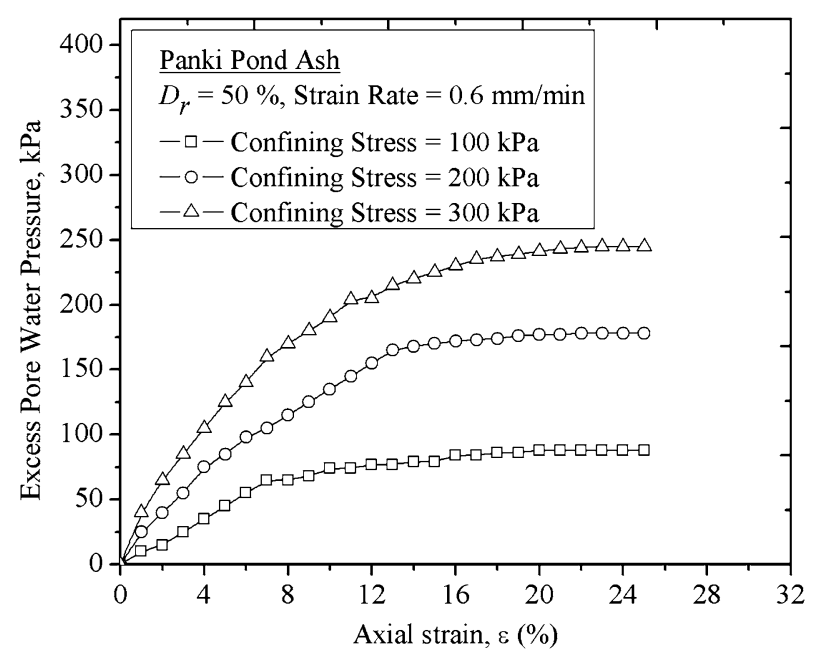

Fig. 9 Excess pore water pressure vs. axial strain curve of Panki Pond Ash $\left(D_{r}=50 \%\right)$

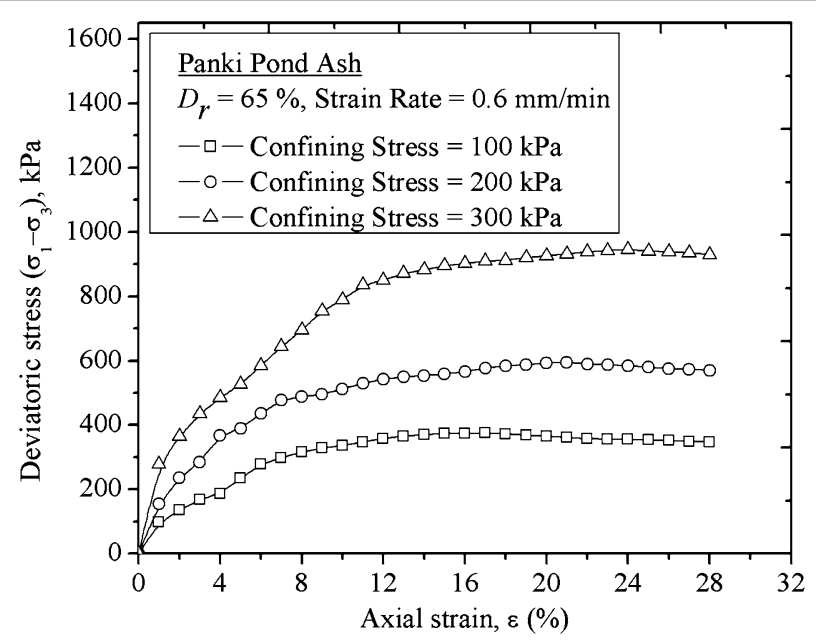

Fig. 10 Deviatoric stress vs. axial strain curve of Panki Pond Ash $\left(D_{r}=65 \%\right)$

It has also been observed that the amount of contraction and excess pore water pressure generation increases with increase in confining pressure for both Panki and Panipat pond ash samples under undrained condition. Panki pond ash shows higher contraction and excess pore water pressure value as compare to Panipat pond ash. In case of $50 \%$ relative density, the peak deviator stress of Panki and Panipat pond ash samples varies from $345.1 \mathrm{kPa}$ to $887.7 \mathrm{kPa}$ and $285.21 \mathrm{kPa}$ to $695.41 \mathrm{kPa}$ with axial strain of $14-22 \%$ and $16-22 \%$ for confining pressures of $100-300 \mathrm{kPa}$ respectively. Similarly for samples tested at $65 \%$ relative density, the variation of peak deviator stress of Panki and Panipat pond ash ranges from 375.23 to $945.14 \mathrm{kPa}$ and 305.02 to $750.31 \mathrm{kPa}$ with axial strain of 17 to $24 \%$ and 19 to $24 \%$ for confining pressure of 100 to $300 \mathrm{kPa}$ respectively. Maximum deviator stress has been used for calculating the effective strength parameters of the pond ash samples. The angle of friction of Panki and Panipat pond ash samples varies from $36.53^{\circ}$ to $37.68^{\circ}$ and $33.04^{\circ}$ to $34.28^{\circ}$ respectively [19] and are presented in 


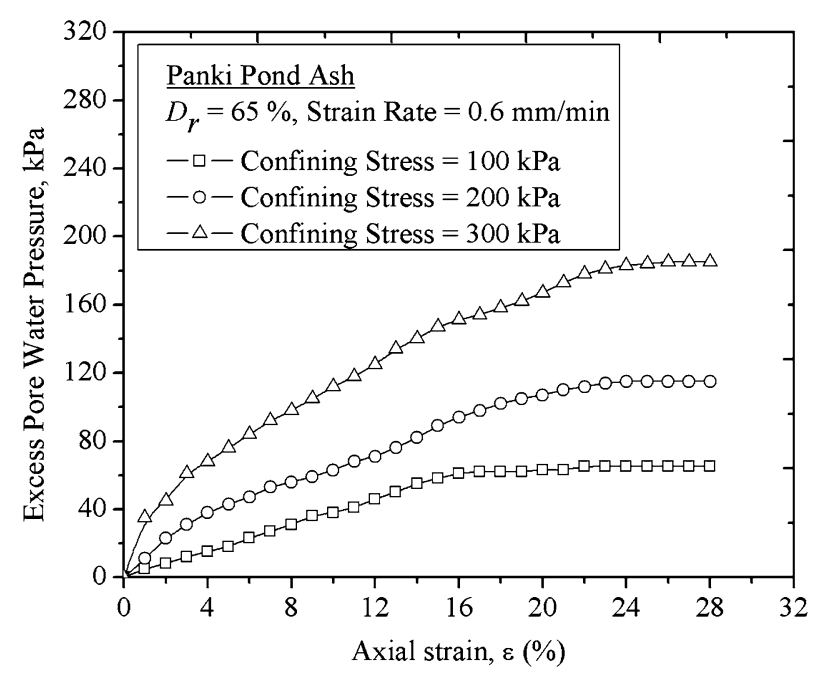

Fig. 11 Excess pore water pressure vs. axial strain curve of Panki Pond Ash $\left(D_{r}=65 \%\right)$

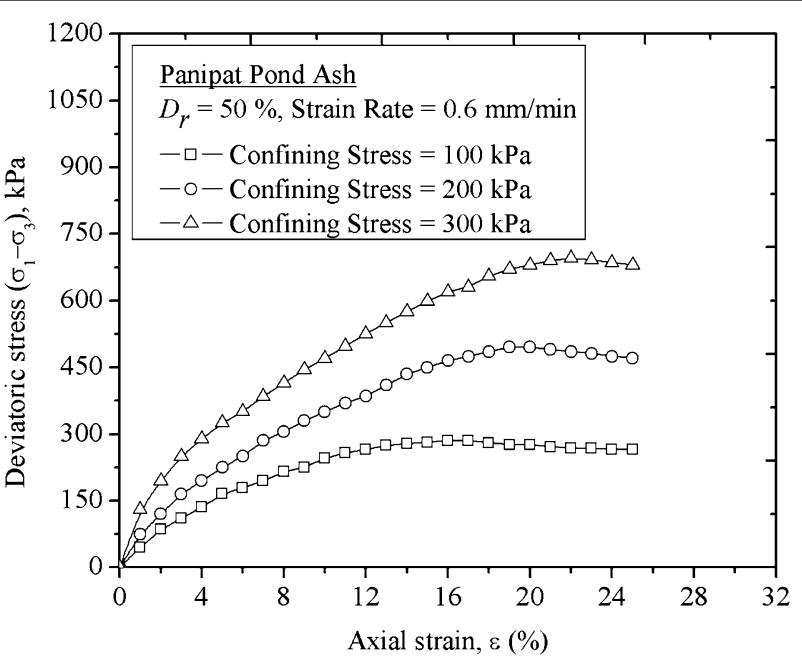

Fig. 12 Deviatoric stress vs. axial strain curve of Panipat Pond Ash $\left(D_{r}=50 \%\right)$

Table 5. The effective cohesion value of both the pond ash samples is found to be zero which indicates non cohesive nature of pond ash.

The reported geotechnical properties of pond ashes, bottom ashes, fly ashes and sand are compared with the geotechnical properties of pond ashes from Panki and Panipat sites and presented in Table 6. It is observed that the specific gravity of Panki and Panipat pond ashes are in the range of specific gravity of reported coal ashes and sand $(1.47-2.72$, Table 6). The results of grain size analysis indicate that the coal ashes (pond ashes, bottom ashes and fly ashes) can be classified as sandy silt to silty sand. Also the maximum dry unit weight of present pond ashes $\left(10.4-11.2 \mathrm{kN} / \mathrm{m}^{3}\right)$ is lesser than that of reported Indian pond ashes and sand $\left(11.6-17.1 \mathrm{kN} / \mathrm{m}^{3}\right)$. However, the maximum dry unit weight of present pond ashes are coming within the range of reported maximum dry unit weights of Indian and United State fly ashes (Table 6). The compression index 


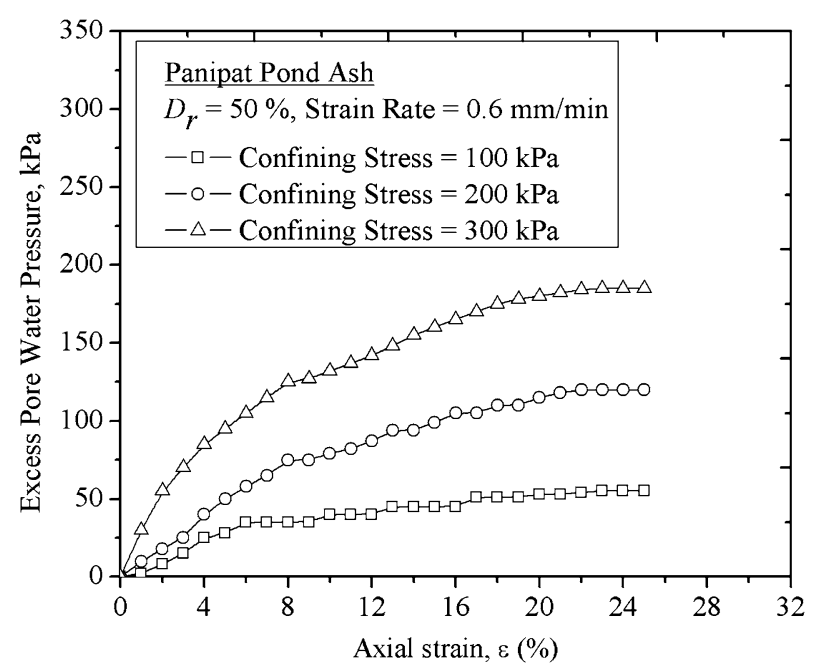

Fig. 13 Excess pore water pressure vs. axial strain curve of Panipat Pond Ash $\left(D_{r}=50 \%\right)$

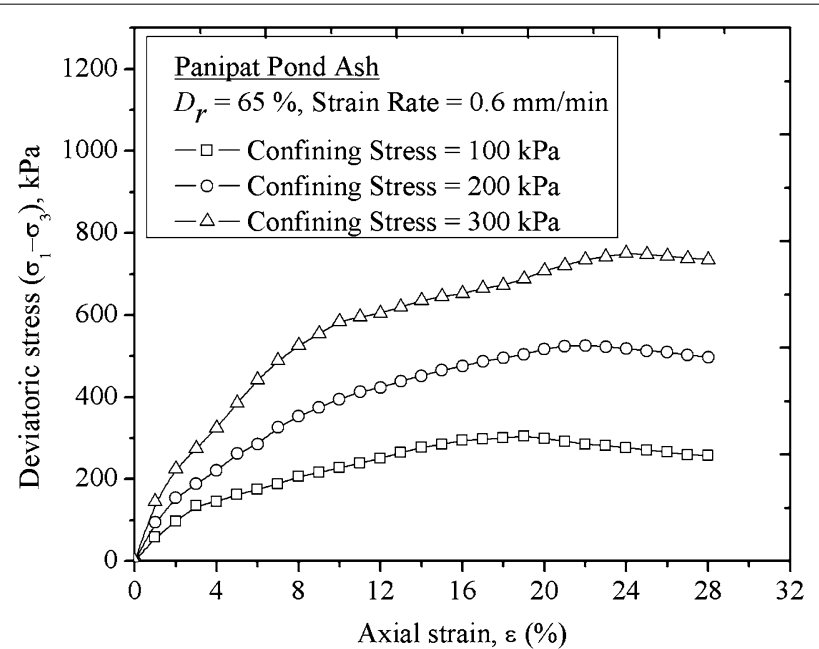

Fig. 14 Deviatoric stress vs. axial strain curve of Panipat Pond Ash $\left(D_{r}=65 \%\right)$

of Panki and Panipat pond ashes $(0.08-0.34)$ are in the range of Indian pond ashes and bottom ashes (0.051-0.484), and United State fly ashes (0.05-0.4). Panipat pond ash shows higher compression index as compared to reported Indian pond ashes, fly ashes and sand. The coefficient of permeability of Panki and Panipat pond ashes (2.42E-05 to $4.21 \mathrm{E}-05)$ are in the range of Yamuna sand (2.1E-05 to 6.0E-05). Pond ashes from Panki and Panipat sites show little higher permeability values as compared to Indian and United State coal ashes. The angle of friction of Panki and Panipat pond ashes (33.04$37.68^{\circ}$ ) are in the range of angle of friction of reported Indian pond ashes and fly ashes, United State fly ashes and sand $\left(25^{\circ}-41.7^{\circ}\right)$.

\section{Conclusions}

A variety of tests were conducted on pond ash samples collected from Panki and Panipat thermal power station to study the physical, chemical, mineralogical, morphological and 


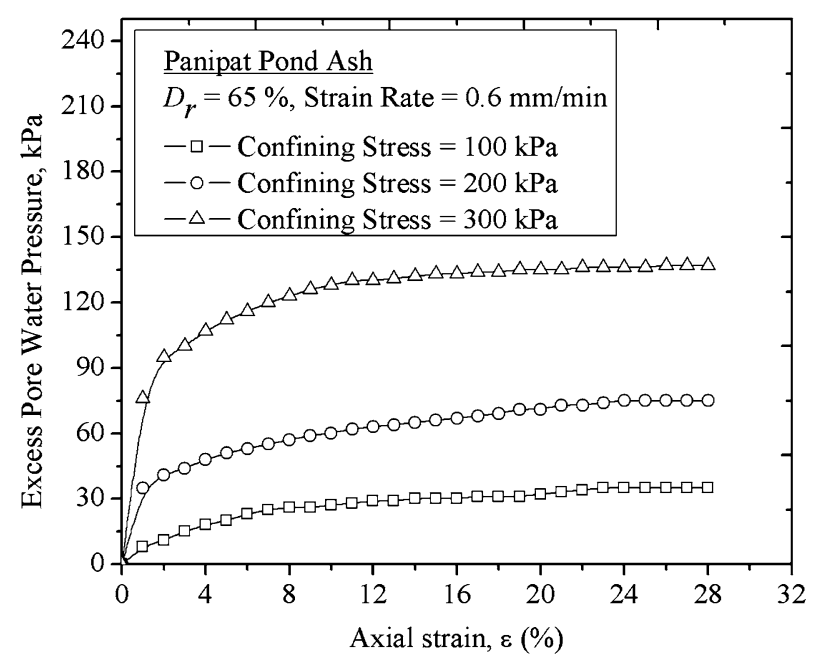

Fig. 15 Excess pore water pressure vs. axial strain curve of Panipat Pond Ash $\left(D_{r}=65 \%\right)$

Table 5 Effective strength parameters of Panki and Panipat pond ashes

\begin{tabular}{lll}
\hline Material & Cohesion, $\boldsymbol{c}^{\prime}(\mathbf{k P a})$ & Angle of friction, $\boldsymbol{\varphi}^{\prime}\left(\mathbf{(}^{)}\right.$ \\
\hline Panki $(50 \% \mathrm{RD})$ & 0 & 36.53 \\
Panki $65 \% \mathrm{RD})$ & 0 & 37.68 \\
Panipat $(50 \% \mathrm{RD})$ & 0 & 33.04 \\
Panipat $(65 \% \mathrm{RD})$ & 0 & 34.28 \\
\hline
\end{tabular}

engineering behavior. Based on the experimental investigations, following are the main conclusions.

1. Both the pond ash samples show low specific gravity value ranges from 2.21 to 2.338 . This may be due to the presence of large amount of hollow cenospheres.

2. XRD results indicate that Panki and Panipat pond ashes predominantly consist of quartz and feldspar minerals. From XRF results it is observed that the proportion of silica, alumina and iron oxides together is about $95 \%$ in both the pond ash samples, taking this into consideration the pond ash samples are classified as class F category.

3. The grain size distribution curve shows that the major portions of pond ashes are coarser particles i.e. sand size fraction with some silt size fraction which can be used for embankment and fill material.

4. Compaction characteristics show that dry unit weight of Panki pond ash is higher than Panipat pond ash. This is mainly due to the higher specific gravity value of Panki pond ash sample.

5. The compression index of Panki and Panipat pond ash samples varies from 0.083 to 0.132 and 0.169 to 0.344 respectively. Similarly the coefficient of permeability of Panki and Panipat pond ash samples varies from $3.78 \mathrm{E}-05 \mathrm{~m} / \mathrm{s}$ to $4.21 \mathrm{E}-05 \mathrm{~m} / \mathrm{s}$ and $2.42 \mathrm{E}-05 \mathrm{~m} / \mathrm{s}$ to $2.93 \mathrm{E}-05 \mathrm{~m} / \mathrm{s}$ respectively which lies in the range of sandy soil and can be used as filter material. 


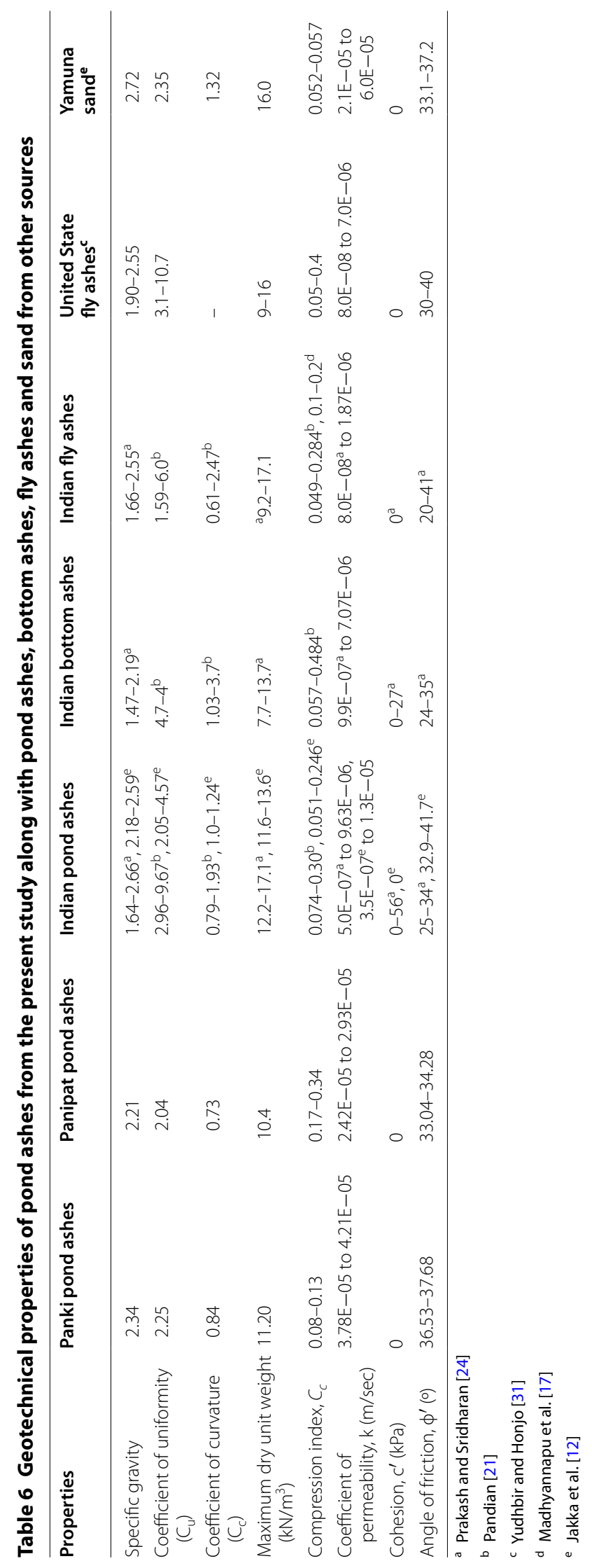


6. The angle of friction of Panki and Panipat pond ash samples varies from $36.53^{\circ}$ to $37.68^{\circ}$ and $33.04^{\circ}$ to $34.28^{\circ}$ respectively. But the effective cohesion value of both the pond ash samples is found to be zero which indicates non cohesive nature of pond ash. From the above results it is observed that pond ash has good potential for use as a material for geotechnical applications like embankment construction, backfill material, filter material etc.

\begin{abstract}
Abbreviations
ASTM: American Society for Testing and Materials; XRD: X-Ray Diffraction; XRF: X-Ray Fluorescence; SEM: scanning electron microscope; CU: consolidated undrained; IS: Indian Standard; ACMS: Advanced Center for Materials Sciences; WDXRF: wavelength dispersive X-ray fluorescence; OMC: optimum moisture content; B: pore pressure parameter; $\triangle \mathrm{u}$ : change in pore pressure; $\Delta \sigma_{c}$ : change in confining pressure.
\end{abstract}

\title{
Authors' contributions
}

SM had conducted the detailed geotechnical characterization of Panki and Panipat pond ash as a part of Ph.D dissertation. NRP had given the research idea, helped in performing experiments and participated in drafting the manuscript. Both authors read and approved the final manuscript.

\section{Author details \\ ${ }^{1}$ Earthquake Engineering Research Centre, International Institute of Information Technology, Hyderabad, Telangana 500032, India. ${ }^{2}$ Geotechnical Engineering Division, Department of Civil Engineering, Indian Institute of Technology Kanpur, Kanpur, Uttarpradesh 208016, India.}

\section{Acknowledgements}

Authors are grateful to Department of Science and Technology, Government of India for providing financial assistance.

\section{Competing interests}

The authors declare that they have no competing interests.

Received: 20 July 2015 Accepted: 23 October 2015

Published online: 02 November 2015

\section{References}

1. ASTM C 618-08a (2008) Standard specification for coal fly ash and raw or calcined natural pozzolan for use in concrete. Annual Book of ASTM Standards

2. Das SK, Yudhbir (2005) Geotechnical characterization of some Indian fly ashes. J Mater Civ Eng ASCE 17(5):544-552

3. Diamond S (1986) Particle morphologies in fly ash. Cem Concr Res 16:569-579

4. Gopalan MK, Haque MN (1986) Strength development of clinically cured plain fly ash concretes. Proc Aust Road Res Board 13:27-33

5. IS: 2720: Part 3 (1980) Methods of test for soils-Determination of specific gravity. Bureau of Indian Standards, New Delhi

6. IS: 2720: Part 7 (1980) Methods of test for soils_-Determination of water content-dry density relation using light compaction. Bureau of Indian Standards, New Delhi

7. IS: 2720: Part 12 (1981) Methods of test for soils-Determination of shear strength parameters of soil from consolidated undrained triaxial compression test with measurement of pore water pressure. Bureau of Indian Standards, New Delhi

8. IS: 2720: Part 4 (1985) Methods of test for soils—Grain size analysis. Bureau of Indian Standards, New Delhi

9. IS: 2720: Part 15 (1986). Methods of test for soils_Determination of consolidation properties. Bureau of Indian Standards, New Delhi.

10. IS: 2720: Part 17 (1986) Methods of test for soils_Laboratory determination of permeability. Bureau of Indian Standards, New Delhi

11. IS: 1893: Part 1 (2002) Indian standard criteria for earthquake resistant design of structures. Bureau of Indian Standards, New Delhi

12. Jakka RS, Ramana GV, Datta M (2010) Shear strength characteristics of loose and compacted pond ash. Geotech Geol Eng 28:763-778

13. Joshi RC, Natt GS, Wright PJ (1981). Soil improvement by lime-fly ash slurry injection. In: Proceedings of 10th International Conference on Soil Mechanics and Foundation Engineering, Stockholm, vol 3, pp 707-712

14. Joslin JG (1958). Ohio's typical moisture density curves. In: Symposium on Soil Testing in Highway Design and Construction, ASTM STP No. 239, pp 111-118

15. Kim B, Prezzi M, Salgado R (2005) Geotechnical properties of fly and bottom ash mixtures for use in highway embankments. J Geotechn Geoenviron Eng ASCE 131(7):914-924

16. Leonard GA, Bailey B (1982) Pulverized coal ash as structural fill. J Geotech Eng Div ASCE 108:517-531

17. Madhyannapu RS, Madhav MR, Puppala AJ, Ghosh A (2008) Compressibility characteristics of sedimented fly ash beds. J Mater Civ Eng ASCE 20(6):401-409 
18. Moghal AAB (2013) Geotechnical and physico-chemical characterization of low lime fly ashes. Adv Mat Sci Eng 2013:1-11

19. Mohanty S, Patra NR (2014) Cyclic behavior and liquefaction potential of Indian pond ash located in seismic zone III and IV. J Mater Civ Eng ASCE 26(7):06014012

20. Nishikawa J, Sato A, Amano K (2002) Utilization of coal ash as fill material. In: Proceedings of 4th International Congress on Environmental Geotechnics, Rio De Janerio, Brazil, A. A. Balkema, Rotterdam, The Netherlands, vol 1, pp 615-618

21. Pandian NS (2004) Fly ash characterization with reference to geotechnical applications. J Indian Inst Sci 84:189-216

22. Parswal IS, Makan OP, Atrea AK (2003) Eco friendly ash management in the form of ash mounds. In: Proceedings of CBIP third International conference-fly ash utilizations and disposal, New Delhi, India. III, pp 10-16

23. Powell MA, Hart BR, Fyfe WS, Sahu KC, Tripathy S, Samuel C (1991) Geochemistry of Indian coal and fly ash, environmental considerations. In: Proceedings of International conference on Environmental Impact of Coal Utilization from Raw Materials to Waste Resources (K. C. Sahu, ed.), Indian Institute of Technology, Bombay, pp 23-38

24. Prakash K, Sridharan A (2009) Beneficial properties of coal ashes and effective solid waste management. Pract Period Hazard Toxic Radioact Waste Manag 13:239-248

25. Raymond S (1961) Pulverized fuel ash as embankment material. Proc Inst Civil Eng 19:515-536

26. Sarkar R, Abbas SM, Shahu JT (2011) Geotechnical characterization of pond ash available in national capital regionDelhi. Inter J Earth Sci Eng 4:138-142

27. Sen Gupta J (1991) Characterization of Indian coal ash and its utilization as building material. In: Proceedings International conference on Environmental Impact of Coal Utilization from Raw Materials to Waste Resources (K. C. Sahu, ed.), Indian Institute of Technology, Bombay, pp 165-184

28. Sridharan A, Pandian NS, Rajasedhar C (1996) Geotechnical characterization of pond ash. In: Raju VS et al (eds) Ash pond and ash disposal systems. Narosa Publishers, Delhi, pp 97-110

29. Sridharan A (2001) Physical, chemical and engineering properties of Indian coal ashes. Nat. Sem. on Utilization of Fly Ash in Water Resources Sector, Central Soil and Material Research Station, New Delhi. pp 15-28

30. Sridharan A (2002) Characterization of Indian coal ashes for geotechnical application. In: Proceedings of Indian Geotechnical Conference, Allahabad, India, pp 700-712

31. Yudhbir, Honjo Y (1991) Application of geotechnical engineering to environmental control. In: Proceedings of 9th Asian Regional conference on Soil Mechanics and Foundation Engineering, Bangkok, 2, pp 431-469

\section{Submit your manuscript to a SpringerOpen ${ }^{\circ}$ journal and benefit from:}

- Convenient online submission

- Rigorous peer review

- Immediate publication on acceptance

- Open access: articles freely available online

- High visibility within the field

- Retaining the copyright to your article

Submit your next manuscript at $\mathbf{s p r i n g e r o p e n . c o m ~}$ 